supported by others, stressed the need for more quantitative information about industry's intake of arts or non-specialist graduates as compared with the intake of specialists of all kinds, the average industrial life of the graduate in any one firm, and the migration of specialists to non-specialist occupations in industry. Information of this kind would go far to assist in dealing with the problem presented by the arts graduate, particularly if, as suggested by Prof. H. S. Kirkcaldy, the arts graduate avoids specialization and acquires the ability to make intelligent use of experts.

\section{SARDINE FISHERY OF CALIFORNIA}

THE fishery for sardines, Sardinops coerulea, is a major industry in California; but there was a disastrous failure of the fishery during the 1947-48 season, and, although slight improvements have taken place in succeeding years, there seems at present little hope of a major recovery before the 1954-55 season at the very earliest. The area of profitable fishing has contracted to the region of southern California, resulting in extensive land transport of fish from there to the processing plants at Monterey and San Francisco.

As an emergency remedial measure the Sardine Industry Advisory Committee introduced a temporary programme of control and management for the 1948-49 season, but this proved unsuccessful and was dropped. Resulting largely from the undiminished initiative of the industry itself, a co-ordinated programme of sardine research by five scientific bodies has been brought into being. The agencies concerned are the California Academy of Seiences, the California Department of Fish and Game, the Stanford University (Hopkins) Marine Station, the United States Fish and Wildlife Service and the University of California (Scripps) Institute of Oceanography.

A progress report covering the period January 1, 1951-June 30, 1952, has recently been published*. The picture that emerges from the work to date is not encouraging. The fish population appears to be so reduced, and the possibility of significant recruitment of young fish so small, that unless the factor of availability operates to increase the normal catch of older fish, the sardine fishery must expect for at least another two seasons the smallest catches for a generation.

Data upon eggs and larvæ, young fish, food and feeding, growth- and mortality-rates, behaviour, schooling patterns and oceanographical conditions are being collected as rapidly as conditions allowbut long-term forecasting is not yet possible.

This important programme of co-ordinated research upon a vast and baffling problem is financed in part by funds from the industry in the form of a tax on landings, in part by a grant from the Federal Government and in part by a grant from the State of California, which makes the largest contribution.

The appearance of further reports on this very ambitious programme is awaited with keen interest, for it represents one of the most intensive combined assaults upon marine biological problems that has anywhere yet been made.

* California Cooperative Sardine Research Program. Progress Report 1 January, 1951, to 30 June, 1952. Pp. 51. (Marine Research 1952.) n.p.

\section{OVERSEAS FOOD CORPORATION}

\section{REPORT FOR THE YEAR 1951-52}

THE annual report of the Overseas Food Corporation for the year ended March 31, 1952*, differs in form from previous reports. Throughout the year the Corporation had been engaged in implementing the terms of the White Paper issued in January 1951, involving the running down of the vast organization built up for the mechanized production of groundnuts in East Africa, and also in an attempt to establish the economics of clearing and mechanized, or partly mechanized, agriculture under tropical conditions. The Corporation is thus now engaged in a large agricultural experiment, and, apart from the chapters on policy, organization and finance, respectively, the bulk of the report deals with the agricultural experiments in the three regions; the chapter on the work of the scientific department is likewise presented on a regional basis. The run-down in the Kongwa area is described in a separate report, appended to the main report, as are the accounts for the year.

The running-down operation has been effected with marked success and without serious detriment to the agricultural work. By March 31, 1952, the Corporation had handed over to the East African Stores Disposal Board about 80 per cent of its surplus stores and equipment, while transfer of the surplus fixed capital assets was virtually complete. The reduction of the European staff by 50 per cent to 636 and of the non-European staff by 18 per cent, giving a ratio of Europeans to non-Europeans of $1: 23$ in place of $1: 14$, proceeded smoothly, and a high proportion of Europeans leaving the service of the Corporation found satisfactory alternative posts in East and Central Africa. The London office has been reduced to a small agency, the Nairobi agency closed, and the Dar-es-Salaam agency incorporated with the general headquarters administration, which moved to Dar-es-Salaam during November 1951. Each region is now administered by a general manager, directly responsible to the chairman in his capacity as chief executive. With the exception of the chief health adviser, who was due to leave in July 1952, the technical advisers had already left the Corporation.

Decentralization of the engineering services is complete, and decentralization of the health department was to be completed when the chief health officer left in July 1952, by which date a reduction in European staff to 38 from the 85 at March 31, 1951, was envisaged. In this final report on health services the opinion is recorded that the danger to the health of Europeans in this area was much exaggerated, and the hospital bed planning figure, originally 2 per cent of the population entitled to treatment, has been reduced to 1 per cent and is being further reduced. The most effective measure for adult mosquito control has proved to be spraying all buildings with 'Gammexane' at three-monthly intervals, and this is now compulsory in Urambo and Nachingwea. Malaria is the commonest disease affecting Europeans, and, although 'Paludrine' has not been used either as a prophylactic or for treating Africans, there is evidence of the emergence of 'Paludrine'-resistant strains of the malaria parasite.

* Overseas Food Corporation. Annual Report and Statement of Accounts for the Year ended 31st March, 1952. Pp. Iv +110. (London: H.M.S.O., 1953.) 38. 6d. net. 
The run-down of Kongwa, which has now been divided into four separate farms with a total area under crop of about twelve thousand acres, presented special probloms as this small area could not support economically the large installations built up to support both a large executive headquarters and three agricultural units each of thirty thousand acres. An administrator was appointed to run-down Kongwa and provide all the necessary services for the farms until they could be made self-sufficient. Kongwa has been declared a township by the Tanganyika Government, and on October 1, 1951, the Public Works Department assumed responsibility for the supply of water and electricity and the maintenance of roads. A small hospital has been retained and receives some contribution to its upkeep from the Tanganyika Government.

Although promising results have been obtained on the Kongwa farms since the Kongwa Working Party reported, experiments must continue for at least one or two seasons before conclusions can be drawn. Novertheless, there are grounds for believing that a rotation in which groundnuts play an important part can be found. It is also evident that the estimated crop yields in both the Southern Province and in Urambo, especially in respect of the groundnuts, which is the main crop, cannot be obtained until much more is learned of the basic agricultural principles to be applied in these difficult areas. Groundnuts appear to be unlikely to play an important part in any rotation for these two areas, at least for several years to come, and accordingly the Board has recommended the slowing-down of the tempo of its operations in both these regions until the economics of the agricultural practices are fully established. Alternative cash crops, which have already stood the test of two seasons, are promising ; and provided that due caution is exercised, it is anticipated that an agricultural pattern will be evolved and a mass of data accumulated which will make a real contribution to the development of these previously uninhabited areas in Africa.

In the Kongwa farms, yields per acre for the 1950-51 season averaged $367 \mathrm{lb}$. for groundnuts, 1,750 lb. for maize and 1,070 lb. for sorghum, and the experience gained during the season indicated that groundnuts should be given priority over maize in the planting programme. Although all seed was treated with 'Agrosan', collar rot (Aspergillus niger) caused considerable seed-bed losses in nuts during periods of dry weather and long periods of wet weather: in trial plantings 'Fernasan' seemed to give better control over collar rot. While trials with giant castor indicated that a fair yield can be expected. in almost any season, there is room for considerable plant-breeding work for standardization in size of seed, time of maturing, etc., while it appears that hibiscus seed can be treated successfully to improve germination.

In the Urambo area yields per acre for the season averaged $404 \mathrm{lb}$. for groundnuts, 1,132 lb. for maize, $557 \mathrm{lb}$. for sorghum, $512 \mathrm{lb}$. for sunflower, $504 \mathrm{lb}$. for soya bean, $53 \mathrm{lb}$. for dwarf beans, $395 \mathrm{lb}$. for tobacco and $3,363 \mathrm{lb}$. for an exporimental crop of rice grown by the. scientific department. Sleeping sickness constitutes a constant threat, although no further cases were discovered, and the elimination and control of Glossina morsitans is a problem of the greatest importance, demanding much further research. A technical committee formed to deal with tsetse control in the area has recommended an approach to the Secretary of State for the Colonies, the East African High Commission and the Government of Tanganyika with the view of formulating and financing a research scheme.

In the Nachingwea area the average yields per acre of the two main crops were $756 \mathrm{lb}$. of groundnuts (in shell) and $1,053 \mathrm{lb}$. of maize; but the results from the cotton crop were unsatisfactory, due probably to late planting and the use of an unsuitable variety. Endeavours are being made to obtain varieties of soya beans suited to the local environment and fit for combine harvesting. Good yields were obtained from different varieties of millet, especially golden millet.

Soil fertility studies by the scientific department in the Kongwa region during 1950-51 were almost wholly concerned with the yellow sandy loams of the Mtanana series. Limestone in exploratory experiments with maize gave a mean increase of yield of $280 \mathrm{lb}$. per acre, and phosphate and lime applied together were the only first-year treatments which raised the yield of maize in the second year. Other experiments were carried out on soil of the Chamaye series to measure the effect of superphosphate, applied to four different crops in the first year, on the yield of groundnuts in the second year and to determine the residual value of eleven different phosphatic fertilizers. Experimental crop studies include trials of different varieties of groundnuts and of the effects of different dates of harvesting, as well as trials of dwarf and semi-dwarf sorghums, Kenya yellow maize, varieties of safflower and dwarf Hungarian castor. Many organic and metallic compounds were tested as seed dressings for groundnuts, and a detailed experiment showed that seed which has been damaged in the slightest degree may fail to germinate. Lesions of Cercospora personata were only found where the disease assumed serious proportions; but it is suspected that viable spores can persist in crop residues and in the ground, and a residue disposal trial was laid down. Infestation of sorghum by stem borers caused considerable losses, and Calidu dregei was also a major pest of sorghum.

In the Urambo region pronounced pedological changes have occurred during the past three years. Accumulation of rainwater in the soils through the complete removal of the natural vegetation has rendered a considerable proportion of the sandy soils unsuitable for mechanized production of arable crops, while there have been heavy losses in reserves of soil nitrogen through the rapid mineralization of organic residues from the woodlands by microbiological activity and subsequent intensive leachings by heavy rains. Soil fertility studies were confined to groundnuts, maize and tobacco. Early planting and the eradication of volunteer groundnuts in the dry season are at the moment the only means in the control of rosette of groundnuts. Stemborer may become a major pest of maize, and infestation of sorghum is also serious. A survey of three thousand acres of groundnuts in the Nachingwea region showed that an average of 3 per cent was rosetted, and a single spraying with 0.5 per cent of a systemic insecticide at 40 gallons per acre appreciably reduced the incidence of the disease. Much attention was given to a study of the biology of the insect vector of the disease. Trials of the effect of two seed dressings on groundnuts suggest thdt hand-picking of seed before treatment would improve the plant stand. Further evidence has been obtained that the soils in the Southern Province are, in general, deficient in phosphates. 